\title{
The Relationship Between Aphis glycines and Soybean mosaic virus Incidence in Different Pest Management Systems
}

\author{
M. E. Lee Burrows, USDA-ARS Plant, Soil and Nutrition Laboratory, Ithaca, NY 14853; and C. M. Boerboom and \\ J. M. Gaska, Department of Agronomy, and C. R. Grau, Department of Plant Pathology, University of Wisconsin- \\ Madison, Madison 53706
}

\begin{abstract}
Burrows, M. E. L., Boerboom, C. M., Gaska, J. M., and Grau, C. R. 2005. The relationship between Aphis glycines and Soybean mosaic virus incidence in different pest management systems. Plant Dis. 89:926-934.

The soybean aphid, Aphis glycines, causes yield loss and transmits viruses such as Soybean mosaic virus (SMV) in soybean (Glycine max). Field experiments were designed to monitor the landing rate of $A$. glycines and transmission of SMV to soybean grown in six crop management environments. Management systems evaluated were the application of postemergence insecticide or no insecticide, and within each insecticide treatment no herbicide, glyphosate, or imazamox application. In 2001, early-season incidence of SMV was 2\%, which increased to 80\% within 18 days after the beginning of the A. glycines flight. In 2002, the incidence of SMV was $1 \%$ prior to the arrival of A. glycines, and increased to $44 \%$ within 21 days. The landing rate of A. glycines was fivefold higher in 2001 than in 2002. The incidence of SMV was lower in insecticide-treated plots in 2002, but no effect of insecticide was seen in 2001. Imazamox slowed the progression of SMV incidence, but the final incidence of SMV-infected plants was the same. Glyphosate had no consistent effect on SMV incidence. Yield was higher in the insecticide-treated plots in 2002, but not 2001. Insecticide and herbicide application had no substantial effects on seed quality.
\end{abstract}

The species and population dynamics of insect pests of soybean (Glycine max (L.) Merrill) have changed dramatically in the north central region of the United States $(15,54)$. The bean leaf beetle (Cerotoma trifurcata Forster) has become a prominent pest of soybean, but the most dramatic change was the introduction of the soybean aphid, Aphis glycines Matsumara. A. glycines was observed in Wisconsin during the summer of 2000 and has expanded its range to most soybean-growing regions in North America $(1,57,60)$. Grain yield is reduced by $A$. glycines by direct physiologic stress (38) and indirectly by transmitting Soybean mosaic virus (SMV) and other soybean viruses $(10,22,57,60)$. Intense feeding by A. glycines causes symptoms of chlorosis, rolled leaves, stunted plants, early maturity, defoliation, and sooty mold growth (Capnodium spp.) on honeydew excreted by the aphids $(58,60)$. A. glycines is the first aphid species capable of colonizing soybean to establish in North America $(1,45)$. It is a vector of SMV in China (60) and has been reported to transmit North American isolates of SMV in controlled experiments $(10,13,22)$.

Corresponding author: Craig R. Grau

E-mail: cg6@plantpath.wisc.edu

Accepted for publication 28 April 2005.

DOI: 10.1094/PD-89-0926

(C) 2005 The American Phytopathological Society
The role of A. glycines in natural epidemics of SMV has not been determined in North America. Epidemiological models for SMV use daily alate aphid flight data to predict the incidence of SMV $(31,46)$. Because the apterous form of $A$. glycines reaches high population densities, current epidemiological models developed for SMV and alate aphid species may not be appropriate.

Current SMV epidemiological models were developed prior to the adoption of glyphosate-resistant soybean varieties. Glyphosate-resistant soybean varieties have been integrated with changes in soybean management practices such as decreasing row space from 0.76 to $0.18 \mathrm{~m}$, reduced or no tillage, and earlier planting dates (3). Alteration of the canopy by herbicides, insects, and fungal pathogens has been shown to be related to yield $(18,40,41)$. Evidence thus far has not linked the application of glyphosate to glyphosate-resistant soybean to diseases caused by fungi and nematodes $(4,7,8,27,32,36,40,49,59)$, but the effect of glyphosate application on viral diseases has not been investigated. It is unknown whether soybean canopy alteration due to pesticide application modifies vector activity and virus epidemiology.

Herbicides that have been shown to alter plant-virus interactions include synthetic auxins (2,4-D) (9), microtubule inhibitors (trifluralin) (28), and photosystem II inhibitors (metribuzin) (11). It was unknown if herbicides used widely in soybean production can alter the epidemiology of
SMV, an economically important virus in soybean (51). Glyphosate and imazamox were selected for this study based on their anticipated effect on canopy structure $(12,17)$. Glyphosate applied to a glyphosate-resistant soybean should have no effect on the canopy (44), whereas imazamox may cause chlorosis, limited necrosis, and shortened internodes for a limited period of time (50).

The effect of soybean canopy closure and plant height on aphid landing rate varies by aphid species $(5,19)$. However, it was not known whether a soybean canopy treated with insecticide and herbicides would alter the immigration and colonization of aphids and the frequency of subsequent virus transmission. The objectives of this study were to characterize the effects of insecticide and the herbicides glyphosate and imazamox on (i) soybean canopy development, (ii) aphid landing rates, (iii) the seasonal progress of SMVinfected plants, and (iv) yield and seed quality.

\section{MATERIALS AND METHODS}

Agronomic protocol. AG2101, a glyphosate-resistant soybean variety (Asgrow; Monsanto, St. Louis, MO), was chosen because of its previous field performance of high incidence of SMV-infected plants, high foliar symptom severity, high incidence of seed coat mottling, and reduced grain yield in the presence of vectors and SMV. Plots were planted at 450,000 seeds per ha on 150 Julian Date (JD), 2001, and 144 JD, 2002, at the West Madison Agricultural Research Station, Madison, WI. Glyphosate (Roundup Ultra, $0.84 \mathrm{~kg}$ a.e./ha; $117 \mathrm{JD})$, metolachlor + safener (Dual II Magnum, $2.14 \mathrm{~kg}$ a.i./ha; $136 \mathrm{JD}$ ), and metribuzin (Sencor, $0.42 \mathrm{~kg}$ a.i./ha; 136 JD) were applied preplant for control of weeds in 2001. In 2002, pendimethalin (Prowl, $1.39 \mathrm{~kg}$ a.i./ha) and metribuzin ( $0.42 \mathrm{~kg}$ a.i./ha) were incorporated into the soil on 135 JD prior to planting.

The experiment was conducted as a randomized complete block design with a split-plot arrangement with four blocks. Insecticide treatment was the main plot, and herbicide subplots were randomized within each insecticide treatment. In 2001, the insecticide lambda-cyhalothrin (Warrior $1 \mathrm{EC}, 0.02 \mathrm{~kg}$ a.i./ha) was applied at growth stages V3 and R1 (184 JD and 201 JD, respectively). Chlorpyrifos (Lorsban 
4E, $0.56 \mathrm{~kg}$ a.i./ha) was applied at R4 on 215 JD for the control of A. glycines and spider mites. In 2002, lambda-cyhalothrin was applied at V3 and R1 (0.02 kg a.i./ha 178 JD and 211 JD). The "no insecticide" treatment plots were sprayed with water. The herbicides glyphosate (Roundup Ultra, $0.84 \mathrm{~kg}$ a.e./ha) and imazamox (Raptor, $0.044 \mathrm{~kg}$ a.e./ha) were sprayed at V3 on 184 JD, 2001, and 178 JD, 2002. The imazamox treatment included crop oil concentrate $(1 \% \mathrm{vol} / \mathrm{vol})$ and urea ammonium nitrate (4.7 liters/ha of 28-0-0) as adjuvants. The no herbicide control plots were not sprayed.

Rows were $75 \mathrm{~cm}$ wide, and 3-m-wide alleys were cut between main plot insecticide treatments for ease of spraying. No alleys were cut between herbicide subplots. Subplots were $9.1 \mathrm{~m}$ wide by $12.2 \mathrm{~m}$ long in 2001 and $18.3 \mathrm{~m}$ wide by $13.7 \mathrm{~m}$ long in 2002. In 2002, the field was irrigated on $180 \mathrm{JD}(1.25 \mathrm{~cm}), 184 \mathrm{JD}(1.25$ $\mathrm{cm}), 192 \mathrm{JD}(2.5 \mathrm{~cm})$, and $200 \mathrm{JD}(2.5$ $\mathrm{cm})$. Plots were not irrigated in 2001. Total natural precipitation from 150 JD to 291 JD, 2001, was $59 \mathrm{~cm}$. Total natural precipitation from $144 \mathrm{JD}$ to $281 \mathrm{JD}, 2002$, was $38 \mathrm{~cm}$.

Inoculum source. In 2001, seed transmission of SMV was not detected after planting 1,000 seeds of a commercial seed lot of soybean variety AG2101. To simulate a seed transmission event, SMV isolate W-180 was used to mechanically inoculate $2.5 \%$ of randomly selected plants in subplots at growth stage V1 (176 JD) in 2001. Plants were randomly selected for inoculation by using a random number generator (Minitab, Inc., State College, PA) to determine the distance in paces from the edge of the subplot. Isolate W180 is a seed and aphid transmissible strain of SMV obtained from a seed lot of variety S20B9 (Northrup King; Syngenta, Golden Valley, MN), which was produced in the presence of SMV at the Arlington Agricultural Research Station in 1999. In 2002, seed harvested from the 2001 experiment was planted, which had a seed transmission rate of $1 \%$ (see results).

Canopy development. Height was recorded for 10 plants in the center $6 \mathrm{~m}$ of the sampling rows on 190, 206, 218, 229, 240, 253, and $275 \mathrm{JD}, 2001$, and 184, 196, 219, 233, and 268 JD, 2002. Canopy development and time to canopy closure was assessed with an LAI 2000 (LI-COR, Inc., Lincoln, NE) on 206, 218, 229, and 253 JD, 2001, and 198, 217, 233, and 253 JD, 2002.

Aphid incidence. The spread of SMV within plots was dependent on naturally occurring populations of aphids. Aphid landing rates were monitored using horizontal mosaic green pan traps filled approximately $2.5 \mathrm{~cm}$ deep with $50 \%$ propylene glycol and water (30). These traps provide an unbiased estimate of the landing rate of aphid species within a soybean canopy (30). One trap was placed in the center of each of 24 subplots, and height was adjusted to within $0.5 \mathrm{~m}$ above the canopy throughout the growing season. In the event of rain, irrigation, or pesticide application, traps were reset after the disturbance event. Aphids were removed from the traps daily and stored in 2.0-ml flatbottomed microcentrifuge tubes (Labsource, Chicago, IL) in $70 \%$ ethanol until identification and enumeration. The number of aphids was recorded, but only $A$. glycines was identified to species. A. glycines was identified by key traits that separate them from closely related species (55). Voucher specimens of A. glycines from this study have been deposited in the University of Wisconsin Department of Entomology Insect Research Collection, Madison.

Colonization by A. glycines was monitored following its initial appearance. In 2001, one insecticide-treated and one noninsecticide-treated subplot were selected using a random number generator (Minitab) from the herbicide treatments in each block. The numbers of aphids on the youngest fully expanded trifoliate of 10 plants per subplot were rated on a 0 to 5 scale, where $0=0$ aphids, $1=1$ to 10 aphids, $2=11$ to 25 aphids, $3=26$ to 99 aphids, $4=100$ to 200 aphids, and $5=$ $>200$ aphids per trifoliate. This rating scheme was used on 191 JD. From 200 to $222 \mathrm{JD}$, the upper two trifoliates were rated. From 226 to 240 JD, the fourth trifoliate from the top was rated. The location of sampling on the plant was altered throughout the season to adjust for the location of aphid colonization. At the beginning of the colonization events, the uppermost leaves in the canopy were the most colonized, whereas later in the growing season, aphids moved lower in the canopy (45). In 2002, the total number of aphids on five plants in each subplot was estimated, except on the last sampling date, $224 \mathrm{JD}$, where only three plants per subplot were assessed. The total number of aphids per plant was used to place the individual plants into the categories used in 2001. To calculate the colonization index, the number of plants in each category was multiplied by the category number $(0$ to 5), and the results were summed for each subplot on each date. This index was used for statistical analysis.

Virus incidence. The incidence of SMV-infected plants was monitored during the growing season using immunological methods. Plants were sampled at growth stages V3, V5, R1, R4, R5, and R6 (183, $190,200,218,240$, and 253 JD) in 2001, and at growth stages V3, R3, R4, R5, R5.5, and R6 (175, 204, 214, 226, 236, and 247 JD) in 2002. The center leaflet of the youngest fully expanded trifoliate was sampled from 30 plants per subplot in 2001 and 60 plants per subplot in 2002. The row where the aphid trap was located and the rows immediately bordering the trap row were not sampled to minimize any effects of walking to the trap each day. Samples were taken in two rows on either side of the trap and bordering rows, for a total of four rows sampled. Leaflets were collected from the center $6 \mathrm{~m}$ of each sampling row to minimize edge effects and maximize sampling intensity $(2,23)$. Leaflets were sampled from rows at approximately regular, arbitrary intervals without evaluating whether the plant was symptomatic. Samples were chilled on ice, stored at $4^{\circ} \mathrm{C}$, and individual leaflets extracted using a leaf press (Ravenel Specialties Corp., Seneca, SC) and $1 \mathrm{ml}$ of phosphate buffered saline (0.15 M PBS, pH 7.2; Agdia, Inc., Elkhart, IN). Sap was placed in 1.5-ml polypropylene microcentrifuge tubes (Labsource), frozen at $-20^{\circ} \mathrm{C}$ for storage, and assayed using a biotin-avidin doubleantibody sandwich enzyme-linked immunosorbent assay (ELISA) with anti-SMV monoclonal antibody $\mathrm{S} 4(1.0 \mu \mathrm{g} / \mathrm{ml})$ as the capture antibody (24), and biotinylated polyclonal anti-SMV antibody $(0.5 \mu \mathrm{g} / \mathrm{ml})$ as the secondary antibody. Alkaline phosphatase conjugated Extravidin $(1: 10,000)$ (Sigma Chemical Co., St. Louis, MO) was followed by $p$-nitrophenyl phosphate (1 $\mathrm{mg} / \mathrm{ml}$ ). Samples were diluted 1:5 with PBS to a final volume of $100 \mu \mathrm{l}$ in a 96well polystyrene microtiter plate (ProBind, Becton-Dickenson, Franklin Lakes, NJ). Positive, negative (healthy, greenhouse-grown soybean leaf tissue), and buffer controls were included on each plate. Samples with absorbance values $(405 \mathrm{~nm})$ that exceeded the mean plus two standard deviations of the negative control were regarded as positive. Any samples with questionable absorbance values were tested again.

Agronomic variables and seed quality. Subplots were harvested 291 JD, 2001, and $281 \mathrm{JD}, 2002$, and yields were adjusted to $13 \%$ moisture content. Six 100-seed subsamples were collected from harvested grain from each subplot to estimate the incidence of seed with mottled seed coats $(39,47)$. The seed transmission of SMV was determined for 400 seeds per subplot. According to calculations where the probability of finding one or more positive plants $=1-[(1-$ probability of transmission $)^{n}$, where $n=$ number of seeds tested, a sample of 400 seeds provides $98 \%$ confidence of detecting a $1 \%$ seed transmission rate, $87 \%$ confidence of detecting a $0.5 \%$ rate, and $67 \%$ confidence of detecting a $0.1 \%$ transmission rate (52). Seedlings were grown in a controlled environment facility (Biotron, University of WisconsinMadison, Madison) at $24^{\circ} \mathrm{C}$ for 2 to 3 weeks to reach growth stage V1 to V2. Seeds were planted in flats approximately $2.5 \mathrm{~cm}$ deep in Superfine Germinating Mix (Conrad Fafard, Inc., Agawam, MA). The number of seedlings that emerged was counted. Leaves from seedlings with 

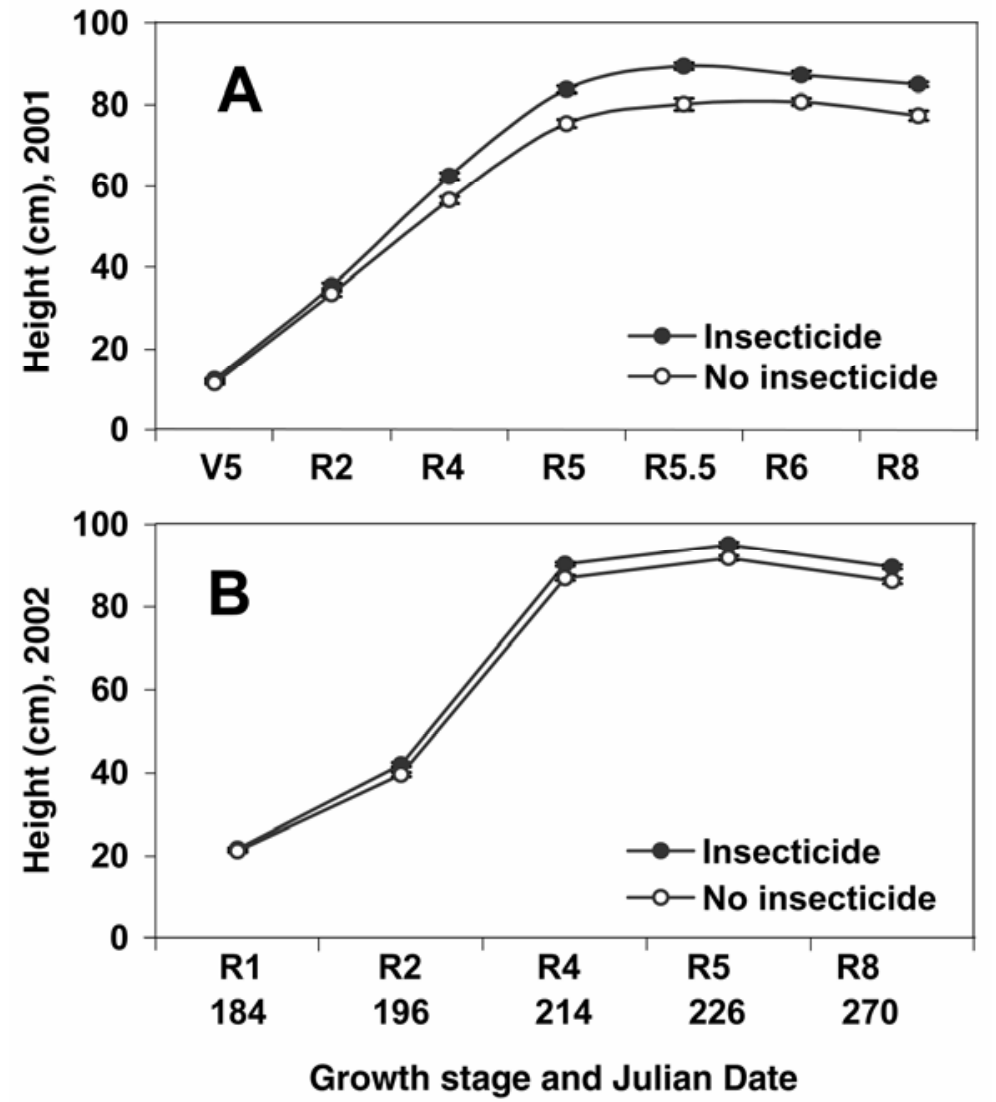

Fig. 1. Soybean height as influenced by insecticide treatment during A, 2001 and B, 2002. Plots of soybean variety AG2101 were located at the West Madison Agricultural Research Station, Madison, WI. Pesticide treatments were arranged in a split-plot design with insecticide (lambda-cyhalothrin or chlorpyrifos) as the main plot and herbicide (glyphosate or imazamox) as the subplot. Data for each insecticide treatment represent the mean for all herbicide treatments. Error bars represent the standard error of the mean. symptoms indicative of virus infection were collected for ELISA confirmation of SMV status. In addition, 10 arbitrarily selected asymptomatic seedlings per flat were tested for SMV. Previous studies and prior experience with variety AG2101 had determined that seedlings without typical virus-like symptoms were not infected with SMV. No asymptomatic, SMVinfected seedlings were observed from these subsamples. Seed transmission was calculated as the number of SMV-positive seedlings divided by the number of seeds that emerged.

Statistical analysis. All statistical analyses were performed with Statistical Analysis System (SAS) for Windows v. 8.2 (SAS Institute Inc., Cary, NC). Means and standard errors were generated with PROC MEANS. Models for continuous variables were analyzed with PROC GLM. Degrees of freedom were: block (replication) $=3$, treatments (insecticide) $=1$, error main plots $($ replication $\times$ insecticide $)=3$, subplots (herbicide) $=2$, subplots $\times$ treatment (herbicide $\times$ insecticide $)=2$, error subplots (replication $\times$ insecticide $\times$ herbicide $)=$ 12 , and total degrees of freedom $=23$. Percentage and count data were analyzed with PROC LOGISTIC. Binary data were analyzed with PROC GENMOD with a binary distribution and a logit link function. Repeated measures comparisons were analyzed with PROC MIXED and an AR(1) error term. Pearson correlations were generated with PROC CORR.

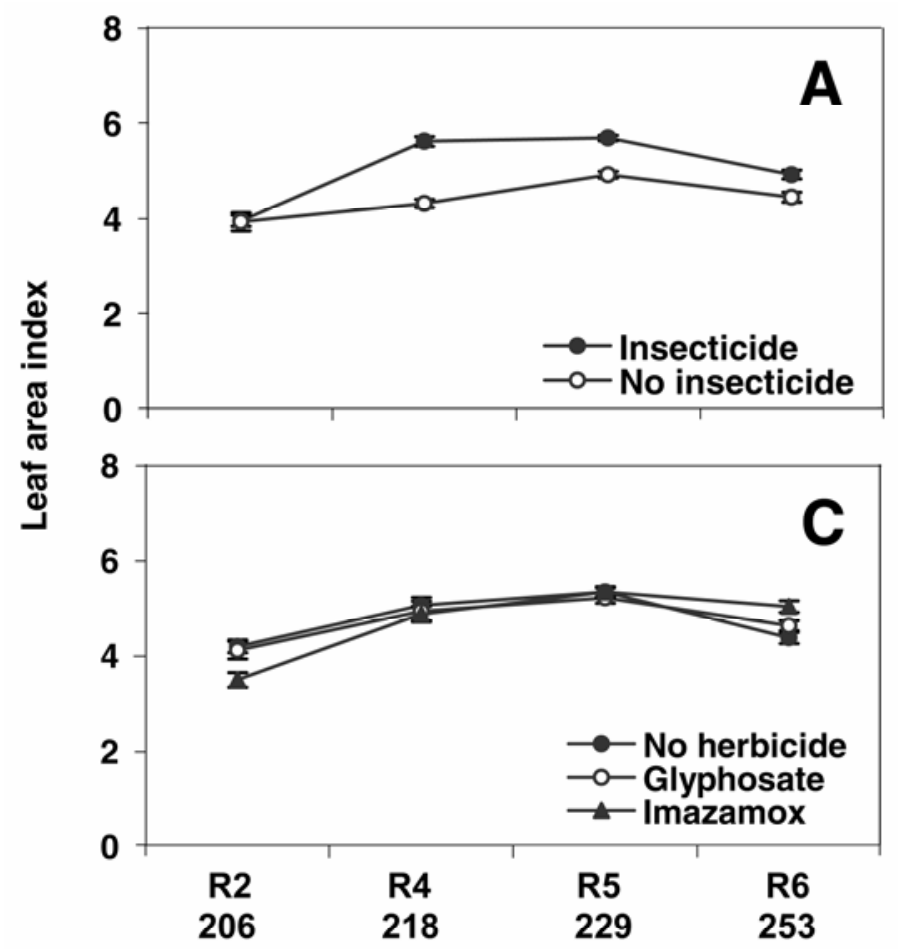

Growth stage and Julian Date, 2001
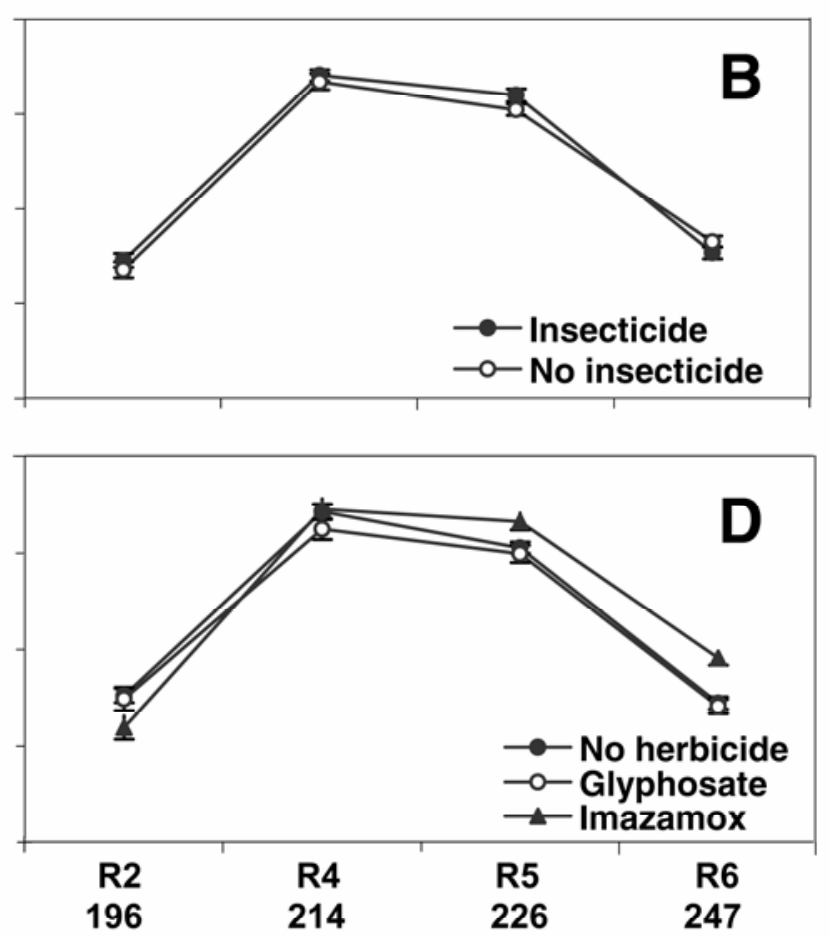

Growth stage and Julian Date, 2002

Fig. 2. Leaf area index of insecticide and herbicide treated plants during A and C, 2001 and $\mathbf{B}$ and D, 2002. Plots of soybean variety AG2101 were located at the West Madison Agricultural Research Station, Madison, WI. Pesticide treatments were arranged in a split-plot design with insecticide (lambdacyhalothrin or chlorpyrifos) as the main plot and herbicide (glyphosate or imazamox) as the subplot. Error bars represent the standard error of the mean. 


\section{RESULTS}

Canopy development. Plant height was used as a measure of canopy development. Insecticide application resulted in increased plant height in both years (repeated measures analysis [RMA]: 2001, $P$ $<0.001 ; 2002, P<0.001$, Fig. 1). The height difference was greater in 2001 than in 2002 (Fig. 1). Plant height was not altered by herbicide in 2001 or 2002 (RMA, $P>0.500)$.

Leaf area index (LAI), a measure of canopy density, was also used to assess the effects of insecticide and herbicide application on canopy development. Soybeans treated with insecticide had significantly increased LAI, as compared to soybeans not treated with an insecticide, in 2001 (RMA, $P<0.001$, Fig. 2A), but not in 2002 (RMA, $P=0.350$, Fig. 2B). Herbicides had a transient effect on the canopy, which was not significant in 2001 or 2002 (RMA, $P>0.500, P=0.059$, Fig. $2 \mathrm{C}$ and D). Imazamox application resulted in decreased LAI as compared to the control at growth stage R2 (2001, $P<0.045 ; 2002, P$ $<0.003)$, but the canopy recovered by growth stage R4 in both years (2001, $P>$ $0.500 ; 2002, P=0.077)$. Imazamox-treated plants also took longer to senesce, as evidenced by the greater LAI at growth stage R6 as compared to the no herbicide treatment (Figs. 2C and D). Glyphosate-treated plants did not differ from the control in 2001 or 2002 (Figs. 2C and D).
Aphid landing rates. The only aphid species landing in significant numbers in horizontal mosaic green pan traps was $A$. glycines during 2001 (89\% of total aphids landing, Fig. 3A) and 2002 (77\% of total aphids landing, Fig. 3B). Aphids of other species were enumerated, but not identified (Fig. 3C and D). In 2001, the first $A$. glycines arrived on $180 \mathrm{JD}$, and a small peak in landing rate of seven aphids per trap occurred at 205 JD (Fig. 3A). The major peak in aphid flight occurred between 211 JD and $231 \mathrm{JD}$, at approximately the R1 growth stage (Fig. 3A). In 2002, similar trends in aphid landing rates were observed. A. glycines was detected in the traps on $157 \mathrm{JD}$, followed by a minor peak of one aphid per trap around 197 JD (Fig. 3B). The major peak in aphid flight occurred 213 JD to $223 \mathrm{JD}$, at approximately the R3 growth stage (Fig. 3B). The number of $A$. glycines landing in each trap during the peak aphid flight in 2001 was 25 aphids/trap/day, fivefold higher than in 2002, where the average landing rate was 5 aphids/trap/day (Figs. 3A and B). The largest number of $A$. glycines collected in a single trap in a 24 -h period was 118 aphids in 2001 versus 18 in 2002.

The landing rate of $A$. glycines was significantly greater in plots treated with insecticide in 2001 (RMA, $P<0.001$; Fig. 4A). The opposite occurred in 2002, and the landing rate of $A$. glycines was significantly less in the insecticide-treated plots
(RMA, $P<0.001$; Fig. 4B). Herbicide treatments did not affect landing rates in 2001 (RMA, $P>0.500$ ) or 2002 (RMA, $P$ $>0.500)$. The landing rates of aphid species other than $A$. glycines were not significantly affected by insecticide or herbicide in either year (data not shown).

Colonization by A. glycines. Insecticide treatments decreased colonizing aphid populations in both years (Fig. 5A and B). Herbicides had no effect on colonizing populations in either year (data not shown). The absolute number of colonizing aphids in each year cannot be directly compared due to different methods of assessing populations, but in 2001 the number of colonizing aphids was visually greater than in 2002 .

Incidence of virus-infected plants. Prior to the major flight of A. glycines, there was an incidence of 0.3 to $3 \%$ SMVinfected plants per subplot between 183 JD to $200 \mathrm{JD}, 2001$ (Fig. 6A). After the initial aphid flights, incidence of SMV-infected plants increased to $80 \%$ by 231 JD. The most rapid advance in incidence of SMVinfected plants occurred in a period of 18 days, from growth stage R1 to R4 (200 JD to $218 \mathrm{JD})$. Incidence reached $100 \%$ by growth stage R5 on $240 \mathrm{JD}$ (Fig. 6A). The increased incidence of SMV-infected plants occurred in conjunction with increased activity of A. glycines (Fig. 6A). In 2002, similar trends were observed for the seasonal incidence of SMV-infected plants.
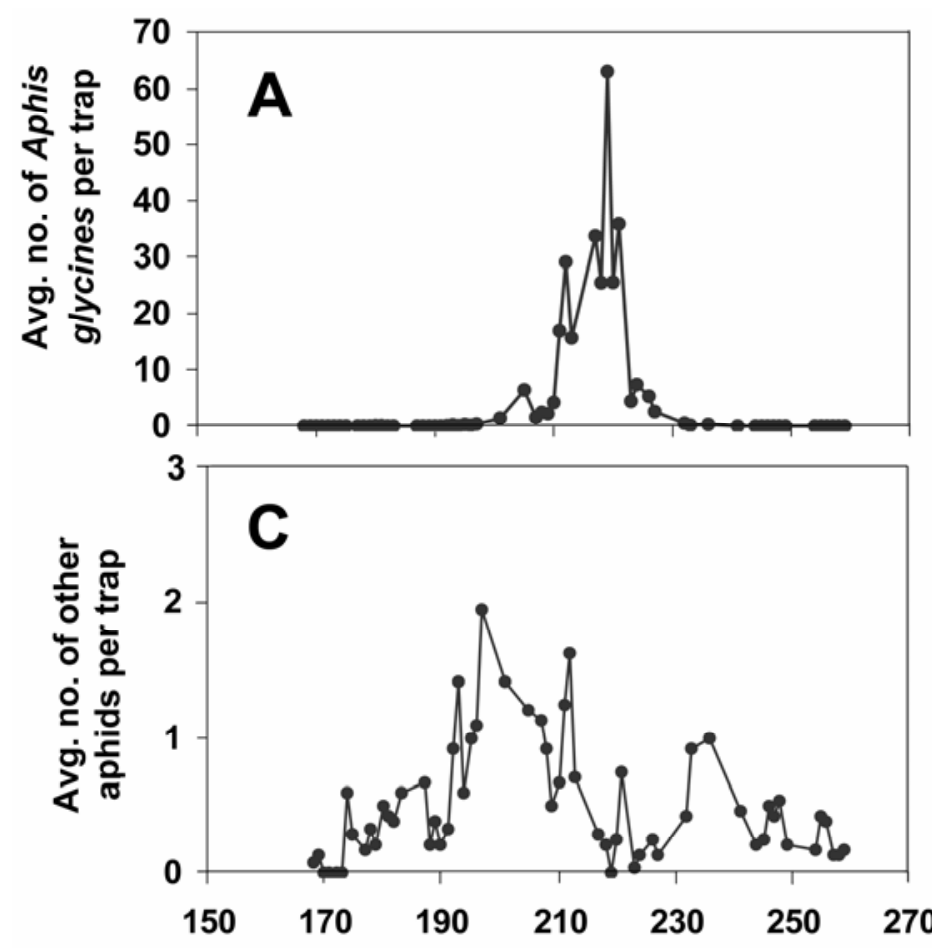

Julian Date, 2001
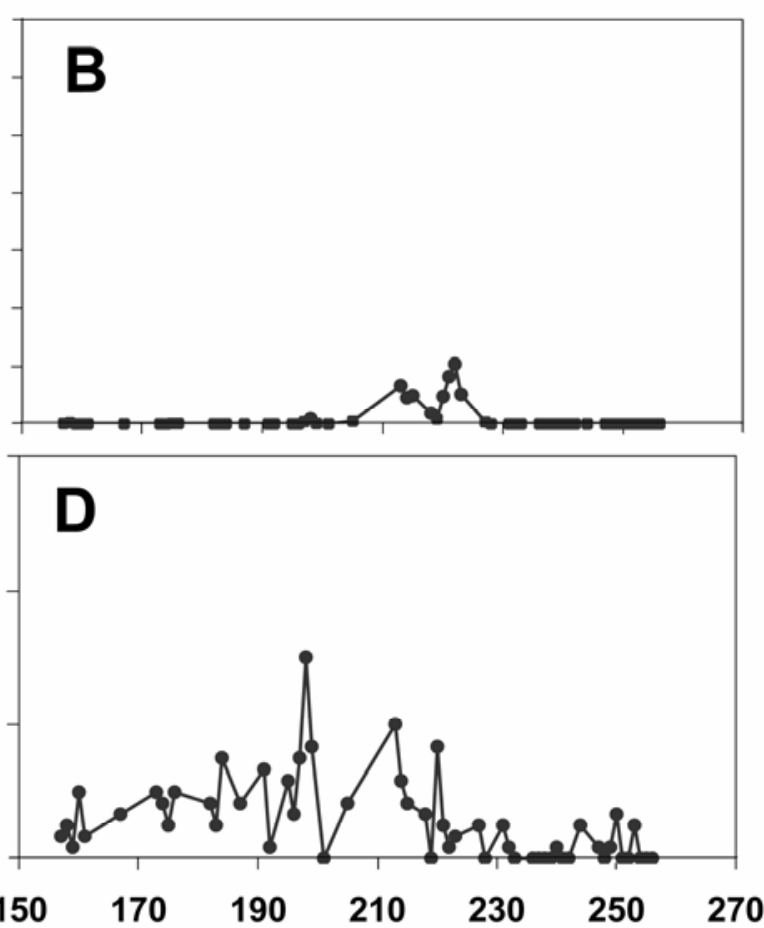

Julian Date, 2002

Fig. 3. Average numbers of Aphis glycines, $\mathbf{A}$ and $\mathbf{B}$, and other aphid species, $\mathbf{C}$ and $\mathbf{D}$, landing in horizontal mosaic green pan traps placed in soybeans receiving insecticide and herbicide treatments during $\mathbf{A}$ and $\mathbf{C}, 2001$ and $\mathbf{B}$ and D, 2002. A. glycines were identified, but other aphids were not identified to species. Traps were located in 24 subplots of soybean variety AG2101 at the West Madison Agricultural Research Station, Madison, WI. Error bars are not included for clarity. 
Prior to the major aphid flight, there was a $1 \%$ incidence of SMV per subplot (Fig. 6B). After the beginning of the aphid flight, the incidence of SMV increased to $20 \%$ by R 4 on $214 \mathrm{JD}$, and then reached a plateau of $44 \%$ at growth stage R5 on 236 JD (Fig. 6B). The incidence of SMVinfected plants did decrease at the last sampling date in both years.

The incidence of SMV was not altered by insecticide in 2001 (RMA, $P>0.500$; Fig. 7A). In 2002, the incidence of SMV was decreased in insecticide-treated plots (RMA, $P=0.001$; Fig. 7B). The final incidence of SMV was not altered by herbicide application in 2001 ( $P>0.500$; Fig. 7C). However, during the greatest period of increase in the incidence of SMV at growth stage R4 (218 JD), there were fewer SMVinfected plants in imazamox-treated plots as compared to the control or glyphosatetreated plots $(P=0.024$; Fig $7 \mathrm{C})$. Again in 2002, imazamox-treated soybean plants had a reduced incidence of SMV prior to growth stage R5 (226 JD) as compared to the control and glyphosate-treated plots $(P=0.002$; Fig. 7D), but the final incidence of SMV at growth stage R6 (247 JD) was equal among the herbicide treatments.
Agronomic and seed traits. In 2001, soybean yield was not altered by insecticide application $(P>0.500$; Table 1$)$. Treatment with imazamox decreased yield $220 \mathrm{~kg} / \mathrm{ha}$ as compared to the control $(P=$ 0.012; Table 1). Yield was not correlated with the incidence of SMV on any date $(P$ $>0.500$ all sampling dates). In 2002, soybean yield was greater in plots treated with insecticide $(P=0.002$; Table 1$)$. Herbicide treatment had no effect on yield $(P>$ 0.500 ; Table 1). Yield was negatively correlated with the incidence of SMV on 236 JD (Pearson correlation $=-0.654, P=$ 0.001 ) and $247 \mathrm{JD}$ (Pearson correlation $=$ $-0.728, P<0.001)$. Correlations at other dates were not significant $(P>0.050)$.

Seed quality was assessed by the amount of seed mottling, seedling emergence, and seed transmission of SMV. The mean incidence of seed with mottled seed coats was $98 \%$ and was not affected by insecticide application in $2001(P>$ $0.500)$, but was increased with imazamox and glyphosate treatment $(P<0.001$; Table 1). In 2002, the incidence of seed coat mottling was $27 \%$, and neither insecticide $(P=0.187)$ nor herbicide $(P=0.441)$ had a significant effect (Table 1).

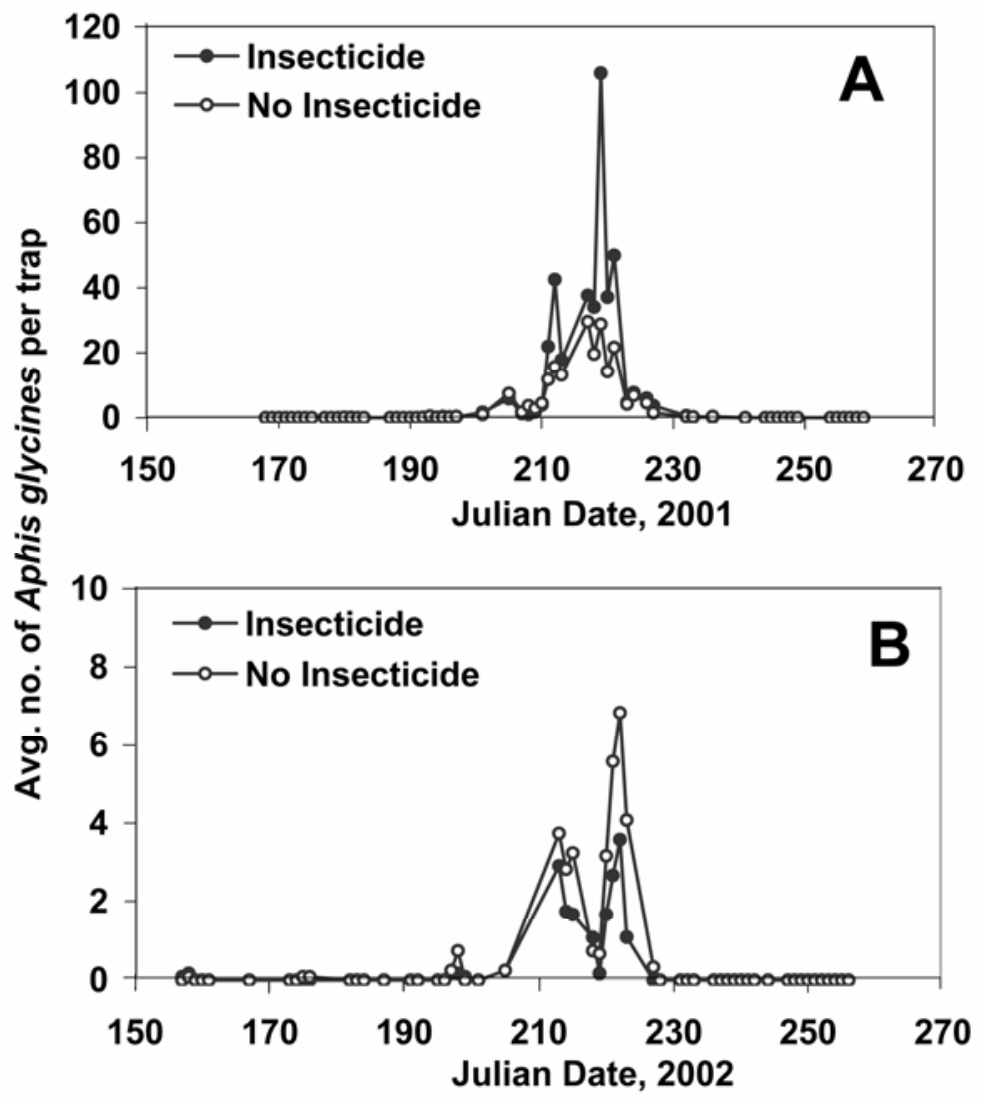

Fig. 4. Average numbers of Aphis glycines landing in horizontal mosaic green pan traps placed in soybeans receiving insecticide treatments during A, 2001 and B, 2002. Data are averaged across all herbicide treatments. Traps were located in 24 subplots of soybean variety AG2101 at the West Madison Agricultural Research Station, Madison, WI in both years. In 2001, insecticide treatments (lambda-cyhalothrin or water) and herbicide treatments (glyphosate or imazamox) were applied 184 JD, and insecticide treatments (lambda-cyhalothrin or water) $201 \mathrm{JD}$ and $215 \mathrm{JD}$ (chlorpyrifos or water). In 2002, insecticide treatments (lambda-cyhalothrin or water) and herbicide treatments (glyphosate or imazamox) were applied $178 \mathrm{JD}$, and insecticide treatments (lambda-cyhalothrin or water) on 211 JD. Error bars are not included for clarity.
Seed was collected from plants each year to determine if insecticide and herbicide treatments would alter seedling emergence. Seedling emergence was $87 \%$ in 2001 , and was not altered by insecticide $(P=0.263)$ or herbicide treatment $(P=0.101)$. In 2002, seedling emergence was $69 \%$, and was not altered by insecticide $(P>0.500)$ or herbicide application $(P=0.101)$.

Seed transmission of SMV was also measured, as the primary source of inoculum each year comes from seed. In 2001, seed transmission of SMV was $1.0 \%$, and was not altered by insecticide $(P=0.339)$ or herbicide $(P=0.462)$ application. In 2002, seed transmission of SMV was $0.09 \%$, and was not affected by herbicide $(P>0.500)$ or insecticide $(P>0.500)$ application.

\section{DISCUSSION}

Data acquired from 2 years of field studies provide evidence that A. glycines transmits SMV in natural epidemics. This conclusion is based on the following results. A. glycines was the predominant aphid species trapped during two growing seasons, and for each season, a rise in SMV-infected plants coincided with increased migration of A. glycines into the soybean canopy. Previous data also support the conclusion that $A$. glycines is a vector of SMV $(14,22,37,61)$. A. glycines has been reported to transmit SMV in controlled transmission studies $(10,22)$, but our experiments are the first to monitor the activity of $A$. glycines and SMV in natural epidemics in North America. Although the timing of alate appearance in traps and the peak of landing rate were similar both years, a greater number of alates were trapped in 2001 as compared to 2002. The final incidence of SMV-infected plants reflected the differences in number of alate A. glycines.

The role of colonizing aphids in the transmission of SMV is unknown. Statistical models have been developed which can predict the rate of SMV spread based on the number and species of alate aphids landing in the soybean canopy (46). Each aphid species is assigned a number reflecting its vector propensity $(20,46)$. A. glycines was the dominant aphid trapped in both years of this study, although other aphid species were present in low numbers. Epidemiological models were developed before the arrival of a colonizing aphid, and it was not known what effect a colonizing aphid would have on the spread of SMV. Flights of alates are preceded by colonization events, and although apterae are not efficient vectors (57) and do not move from plant to plant as frequently as alatae, the number of colonizing aphids feeding and the production of alate aphids by the colonizing population could be important in virus spread.

The arrival of $A$. glycines in the north central United States raised immediate 
concerns that SMV and other aphidtransmitted viruses could become problematic to soybean production. The effectiveness of insecticides for the control of a nonpersistent virus by a colonizing aphid in soybean was unknown. Also, it was unknown what effect recent alterations in soybean management, particularly the use of herbicides, would have on virus epidemiology. We attempted to alter the canopy of soybeans with insecticide and herbicides, and to measure the effect of management practices on alate $A$. glycines landing rate, colonizing aphid populations, virus incidence, yield, and seed quality. Although insecticide did decrease the number of colonizing aphids, it did not completely eliminate them. When the number of colonizing aphids was managed by the use of insecticide, plant height was increased in both years of the study, and canopy density increased in 2001. We cannot discriminate between alate aphids moving between fields and those produced within the field using the pan traps, but it is reasonable to assume there are more alates produced in plots with more colonizing aphids. In 2001, the number of aphids landing in insecticide-treated plots was greater than those landing in plots not treated with insecticide. This may be due to differences in the canopy. There were a great number of aphids, and a thicker canopy may have been attractive to local and migrating alates. Aphids are generally attracted to edge areas and less developed canopies $(5,19,29)$. However, Aphis spiraecola Patch and Myzocallis punctatus Monell land more frequently in a more dense canopy (19). In 2002, there were fewer alates overall, and the majority of migrants detected may have been traveling shorter distances. This would explain why there were more alates within the plots with more apterae (non-insecticide-treated plots).

The 2 years of this study were very different in terms of the density of alate and colonizing populations of A. glycines. The incidence of SMV increased from 3 to $80 \%$ in 18 days in 2001 , and from 5 to $20 \%$ in 9 days in 2002. The incidence of SMV then doubled from 20 to $40 \%$ in 12 days in 2002, with relatively low aphid populations. We observed a decrease in the detection of SMV on the last sampling date in both 2001 and 2002. It is not known why this occurred, but we postulate the virus may have been more difficult to detect in older leaf tissue. There was no difference in the progress of SMV incidence in 2001 due to insecticide treatment. The system may very well have been overwhelmed, whereas in 2002 there was less inoculum (1\% versus $2.5 \%$ in 2001) and fewer aphids, allowing us to more closely follow the progress of the epidemic. Further investigation into how canopy structure influences the movement of A. glycines may be valuable in the development of management strategies.

We were particularly interested in whether the herbicides glyphosate and imazamox would alter the epidemiology of SMV. The application of herbicides did not affect the landing rates of aphid species or the number of colonizing aphids in either 2001 or 2002. There were no height or LAI differences due to herbicides at the time of peak aphid flight. Glyphosate treatment did not alter the epidemiology of SMV. However, imazamox slowed the increase of SMV in both years in this study. Additional field and laboratory experiments suggest imazamox may slow or

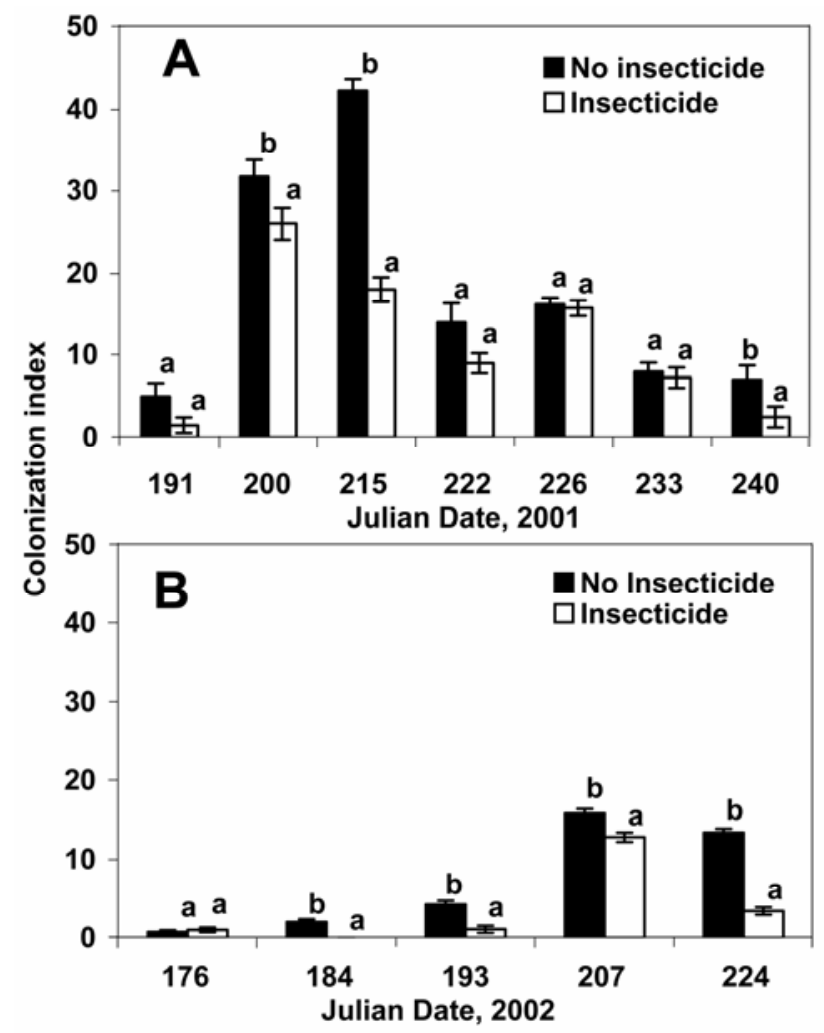

Fig. 5. Insecticide effects on the number of colonizing Aphis glycines on soybean plants in A, 2001 and B, 2002. Plots of soybean variety AG2101 were located at the West Madison Agricultural Research Station, Madison, WI. Results are averaged over all herbicide treatments. In 2001, insecticide treatments (lambda-cyhalothrin or water) and herbicide treatments (glyphosate or imazamox) were applied $184 \mathrm{JD}$, and insecticide treatments (lambda-cyhalothrin or water) $201 \mathrm{JD}$ and $215 \mathrm{JD}$ (chlorpyrifos or water). In 2002, insecticide treatments (lambda-cyhalothrin or water) and herbicide treatments (glyphosate or imazamox) were applied 178 JD, and insecticide treatments (lambda-cyhalothrin or water) on 211 JD. Error bars represent the standard error of the mean. Letters represent a least significant difference $(P=0.05)$ comparison of the means within each date.

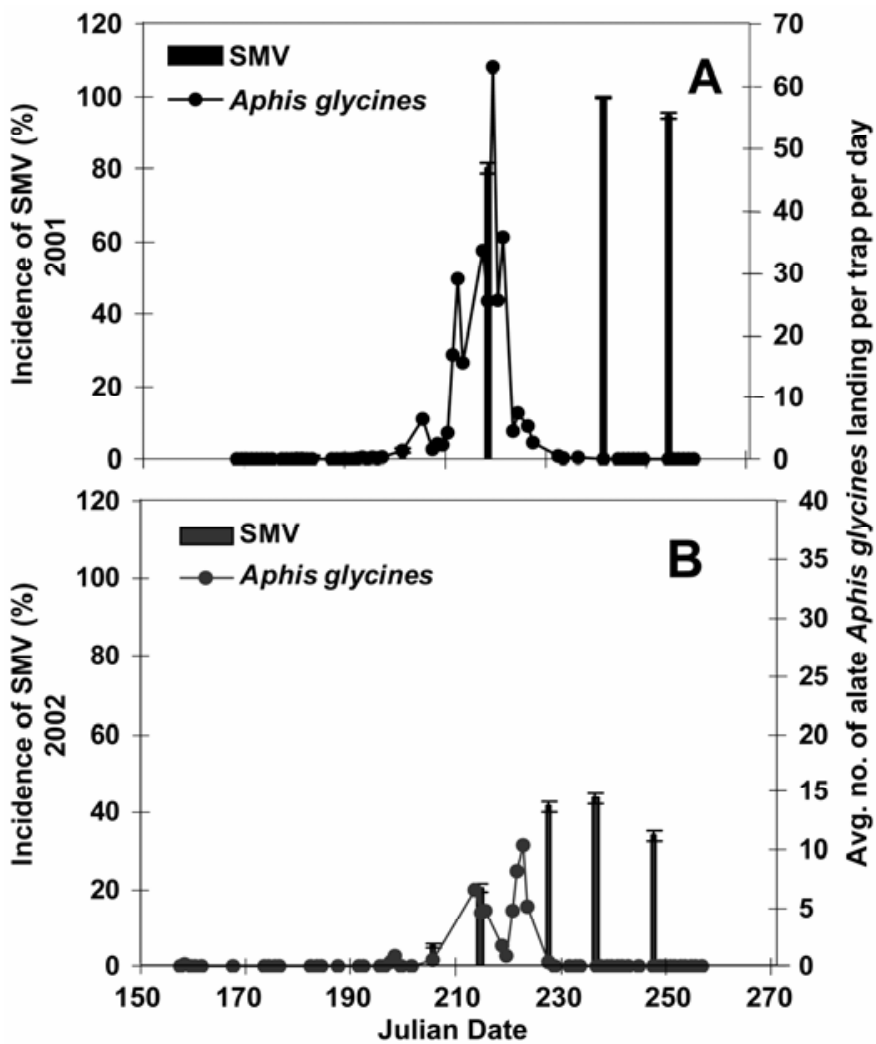

Fig. 6. The relationship between the incidence of Soybean mosaic virus (SMV) in soybean and numbers of alate Aphis glycines caught in horizontal mosaic green pan traps in A, 2001 and B, 2002 when averaged over insecticide and herbicide treatments. Traps were located in the center of each of 24 subplots of soybean variety AG2101 located at the West Madison Agricultural Research Station, Madison, WI under A. glycines and SMV pressure. Pesticide treatments were arranged in a split-plot design with insecticide (lambdacyhalothrin or chlorpyrifos) as the main plot and herbicide (glyphosate or imazamox) as the subplot. Error bars for SMV incidence represent the standard error of the mean. Error bars for A. glycines alate landing rates are not included for clarity. 
prevent infection of the soybean plant with SMV (34). Imazamox blocks amino acid synthesis and subsequently the synthesis of DNA and stops cell division, inhibits transport of photosynthate out of the leaves to the roots, decreasing protein synthesis and transpiration (50). These processes could directly affect replication, encapsidation, and movement of a virus. However, imazamox is most active within the plant from 12 to $24 \mathrm{~h}$ after application (50), and these plants were sprayed at V3, a month before peak aphid activity and virus spread. The mechanism by which imazamox may alter the plant-virus interaction is unknown.

Yield and seed quality, including seed transmission, are of primary importance as we assess the effects of A. glycines on the soybean plant. Yield was not affected by insecticide in 2001, but insecticide increased yield by $460 \mathrm{~kg} / \mathrm{ha}$ in 2002. Other studies in Wisconsin at this time with similar aphid populations, but less SMV inoculum, found a yield benefit with insecticide application. The lack of a yield benefit in our study in 2001 may have been due to the high incidence of SMV, which was $100 \%$ by growth stage R5. SMV has been shown to reduce yield in many studies (42,53). An alternative explanation is that insecticide was not applied at ideal inter- vals to control peak A. glycines populations and receive a yield benefit.

Seed quality was assessed by the amount of seed coat mottling and the incidence of seed transmission of SMV. Seed coat mottling decreases the value of food grade seed and can indicate infection of the mother plant with viruses such as SMV
$(15,26,33)$. Insecticide and herbicide did not consistently alter the incidence of seed coat mottling. Seed transmission of SMV was essential to determine because it provides the primary inoculum source for SMV each field season (25). Seed transmission of SMV in both 2001 and 2002 was very low, and there were no treatment

Table 1. The effects of herbicide and insecticide applications and their interactions on yield and seed mottling during 2001 and 2002 at the West Madison Agricultural Research Station, with Soybean mosaic virus and Aphis glycines pressure

\begin{tabular}{lllllll}
\hline & & \multicolumn{2}{c}{ Yield $^{\mathbf{x}}(\mathbf{k g} / \mathbf{h a})$} & & \multicolumn{2}{c}{ Mottling } \\
\cline { 3 - 4 } \cline { 5 - 6 } Insecticide & & $\mathbf{2 0 0})$ \\
\hline No insecticide & Herbicide & $2,920 \mathrm{a}$ & $3,450 \mathrm{a}$ & & $98 \mathrm{a}$ & $28 \mathrm{a}$ \\
Insecticide & & $2,910 \mathrm{a}$ & $3,910 \mathrm{~b}$ & & $98 \mathrm{a}$ & $26 \mathrm{a}$ \\
& No herbicide & $3,020 \mathrm{~b}$ & $3,750 \mathrm{a}$ & & $97 \mathrm{a}$ & $26 \mathrm{a}$ \\
& Glyphosate & $2,930 \mathrm{ab}$ & $3,600 \mathrm{a}$ & & $98 \mathrm{~b}$ & $27 \mathrm{a}$ \\
& Imazamox & $2,800 \mathrm{a}$ & $3,690 \mathrm{a}$ & & $99 \mathrm{~b}$ & $28 \mathrm{a}$ \\
No insecticide & No herbicide & $2,980 \mathrm{a}$ & $3,600 \mathrm{abc}$ & & $97 \mathrm{a}$ & $25 \mathrm{a}$ \\
No insecticide & Glyphosate & $2,890 \mathrm{a}$ & $3,280 \mathrm{a}$ & & $98 \mathrm{~b}$ & $30 \mathrm{a}$ \\
No insecticide & Imazamox & $2,880 \mathrm{a}$ & $3,470 \mathrm{ab}$ & & $99 \mathrm{~b}$ & $29 \mathrm{a}$ \\
Insecticide & None & $3,056 \mathrm{a}$ & $3,910 \mathrm{c}$ & & $97 \mathrm{a}$ & $28 \mathrm{a}$ \\
Insecticide & Glyphosate & $2,960 \mathrm{a}$ & $3,930 \mathrm{c}$ & & $97 \mathrm{a}$ & $23 \mathrm{a}$ \\
Insecticide & Imazamox & $2,720 \mathrm{a}$ & $3,900 \mathrm{bc}$ & & $99 \mathrm{~b}$ & $28 \mathrm{a}$ \\
\hline
\end{tabular}

${ }^{\mathrm{x}}$ Numbers followed by the same letter within each main effect, interaction, and year are not significantly different from each other at $P=0.05$. Mean separations were performed using least significant difference.

${ }^{y}$ Numbers followed by the same letter within each main effect, interaction, and year are not significantly different from each other at $P=0.05$. Mean separations were performed using contrasts.

${ }^{\mathrm{z}}$ Incidence of seed with symptoms of seed coat mottling.
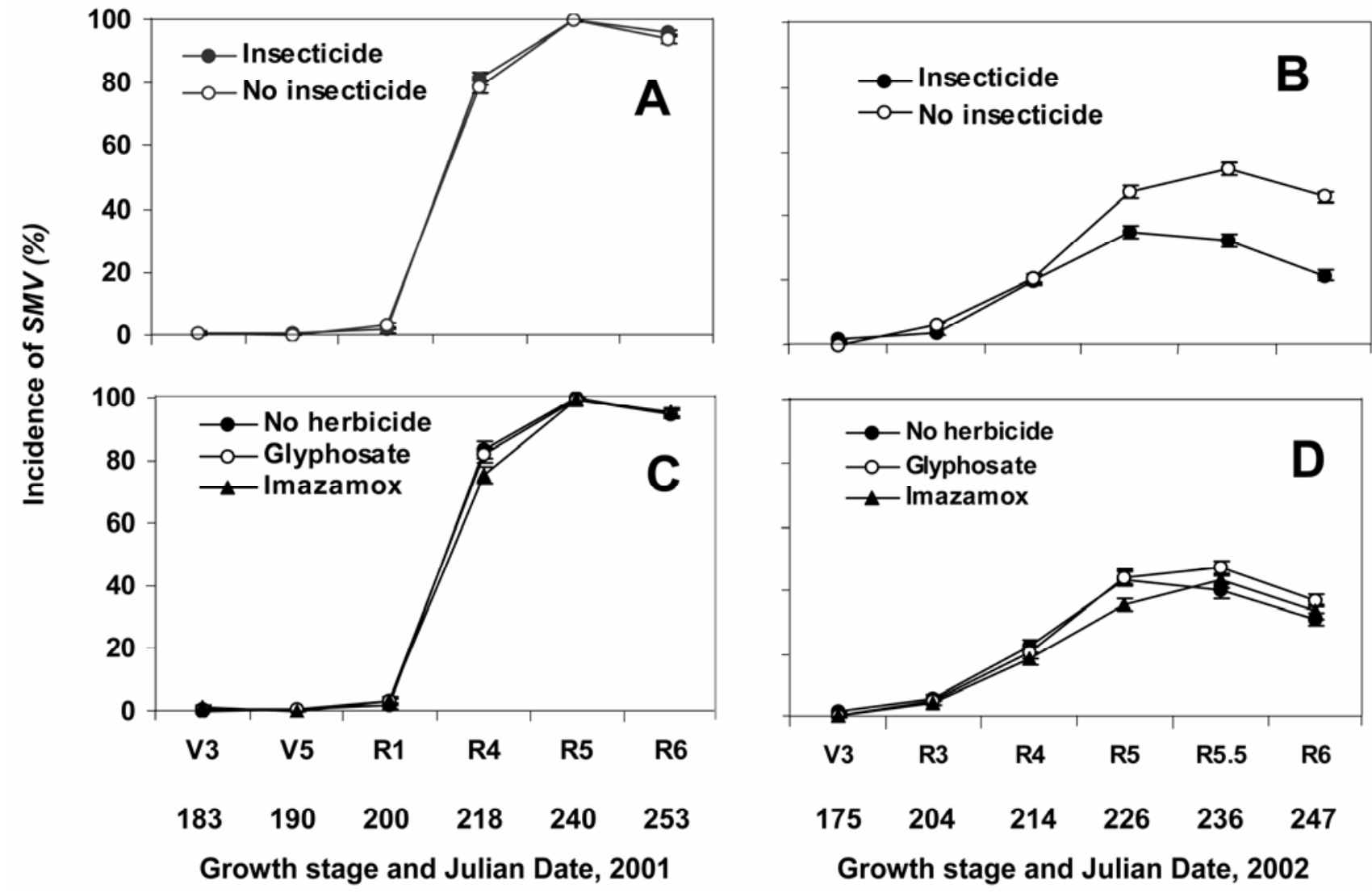

Fig. 7. Insecticide and herbicide effects on the incidence of Soybean mosaic virus (SMV) in soybean in A, 2001 and B, 2002. Plots of soybean variety AG2101 were located at the West Madison Agricultural Research Station, Madison, WI. In 2001, insecticide treatments (lambda-cyhalothrin or water) and herbicide treatments (glyphosate or imazamox) were applied $184 \mathrm{JD}$, and insecticide treatments (lambda-cyhalothrin or water) $201 \mathrm{JD}$ and $215 \mathrm{JD}$ (chlorpyrifos or water). In 2002, insecticide treatments (lambda-cyhalothrin or water) and herbicide treatments (glyphosate or imazamox) were applied 178 JD, and insecticide treatments (lambda- cyhalothrin or water) on 211 JD. Error bars represent the standard error of the mean. 
effects. However, seed transmission rates as high as $90 \%$ have been reported in older germ plasm $(6,43)$. Variety improvement and the identification of resistance genes to SMV have made it a less significant pathogen today than in previous years $(6,16,21)$. With the introduction of a very efficient insect vector which is now ubiquitous in the Upper Midwest and Canada, SMV may again become an important pathogen in the areas where both the virus and the aphid are present.

A. glycines is now an established pest on soybeans in North America. Since its first discovery in Wisconsin (10), it has expanded its range across North America in soybean growing areas. At the time these studies were initiated, very little was known about the aphid's biology in the United States and Canada. Since then, it has been determined how the aphid overwinters (56), its natural enemies (48), and its capacity as a vector $(10,22,34,35,57)$. Our results are very similar to those seen in Asia, where the aphid has been a problem for many years (60). In both Asia and Wisconsin, it has been found that A. glycines is an important vector of SMV, the incidence of SMV is closely related to the presence of alate aphids, and A. glycines represents the most abundant aphid species in soybeans, accounting for $64 \%$ of the total alate aphids in Chinese studies and 77 to $89 \%$ in these experiments (60). Fundamental research is underway to find the best methods to control $A$. glycines and the viruses it spreads.

\section{ACKNOWLEDGMENTS}

We thank Nancy Kurtzweil, Tom German, Bob Ellingson, Emily Mueller, Faith Bartz, and Laurie Faccio for their valuable contributions to this research. We thank Mike Irwin and Gail Kampmeier for lending us tiles and valuable input on sampling, aphid identification, and aphid behavior. We thank David Voegtlin for advice on aphid identification. John Hill and Ana Maria Mondjana provided antibodies and critical input. We also thank the UWCALS statistical consulting service, especially Rebecca Hozak and Jun Yan, and Sean Burrows for help with data analysis. This study was funded by the College of Agriculture and Life Sciences, University of Wisconsin-Madison, the Wisconsin Soybean Marketing Board, the North Central Soybean Research Program, and the USDA North Central Integrated Pest Management Program. First author was supported by an NSF predoctoral fellowship and NIH Biotechnology Training Fellowship (NIH 5 T32 GM08349).

\section{LITERATURE CITED}

1. Alleman, R. J., Grau, C. R., and Hogg, D. W. 2002. Soybean aphid host range and virus transmission efficiency. Proc. Wisc. Fertilizer, Aglime, Pest Manage. Conf., Madison, WI.

2. Barnett, O. W. 1986. Surveying for plant viruses: Design and considerations. Pages 147166 in: Plant Virus Epidemics: Monitoring, Modeling, and Predicting Outbreaks. G. D. McLean, ed. Academic Press, North Ryde, NSW.

3. Bertram, M. G., and Pedersen, P. 2004. Adjusting management practices using glyphosateresistant soybean cultivars. Agron. J. 96:462468.

4. Black, B. D., Russin, J. S., Griffin, J. L., and
Snow, J. P. 1996. Herbicide effects on Rhizoctonia solani in vitro and rhizoctonia foliar blight of soybean (Glycine max). Weed Sci. 44:711-716.

5. Bottenberg, H., and Irwin, M. E. 1992. Canopy structure in soybean monocultures and soybean-sorghum mixtures: Impact on aphid (Homoptera: Aphididae) landing rates. Environ. Entomol. 21:542-548.

6. Bowers, G. R., and Goodman, R. M. 1982. New sources of resistance to seed transmission of soybean mosaic virus in soybeans. Crop Sci. 22:155-156.

7. Bradley, C. A., Noel, G. R., Grau, C. R., Gaska, J. M., Kurtzweil, N. C., MacGuidwin, A. E., Wax, L. M., Hartman, G. L., and Pedersen, W. L. 2003. Impact of herbicides on Heterodera glycines susceptible and resistant soybean cultivars. J. Nematol. 35:88-97.

8. Brammall, R. A., and Higgins, V. J. 1988. The effect of glyphosate on resistance of tomato to Fusarium crown and root rot disease and on the formation of host structural defense barriers. Can. J. Bot. 66:1547-1555.

9. Cheo, P. C. 1969. Effect of 2,4dichlorophenoxyacetic acid on tobacco mosaic virus infection. Phytopathology 59:243-244.

10. Clark, A. J., and Perry, K. L. 2002. Transmissibility of field isolates of soybean viruses by Aphis glycines. Plant Dis. 86:1219-1222.

11. Corsini, D. L., Callihan, R. H., and Garner, J. G. 1983. The effect of metribuzin interaction with potato viruses $\mathrm{X}$ and $\mathrm{Y}$ on potato foliage, yield and grade. Am. Potato J. 60:301-308.

12. Delannay, X., Bauman, T. T., Beighley, D. H., Buettner, M. J., Coble, H. D., DeFelice, M. S., Derting, C. W., Diedrick, T. J., Griffin, J. L., Hagood, E. S., Hancock, F. G., Hart, S. E., LaVallee, B. J., Loux, M. M., Lueschen, W. E., Matson, K. W., Moots, C. K., Murdock, E., Nickell, A. D., Owen, M. D. K., II, E. H. P., Prochaska, L. M., Raymond, P. J., Reynolds, D. B., Rhodes, W. K., Roeth, F. W., Sprankle, P. L., Tarochione, L. J., Tinius, C. N., Walker, R. H., Wax, L. M., Weigelt, H. D., and Padgette, S. R. 1995. Yield evaluation of a glyphosate-tolerant soybean line after treatment with glyphosate. Crop Sci. 35:1461-1467.

13. Domier, L. L., Latorre, I. J., Steinlage, T. A., McCoppin, N., and Hartman, G. L. 2003. Variability and transmission by Aphis glycines of North American and Asian Soybean mosaic virus isolates. Arch. Virol. 148:1925-1941.

14. D'yakonov, K. P. 1975. Aphis glycines Mats. (Homoptera, Aphididae) as a vector of soybean mosaic virus in the south of the Soviet Far East. Trudy Biologo-Pochvennogo Instituta 28:147-150.

15. Giesler, L. J., Ghabrial, S. A., Hunt, T. E., and Hill, J. H. 2002. Bean pod mottle virus: A threat to U.S. soybean production. Plant Dis. $86: 1280-1289$

16. Gunduz, I., Buss, G. R., Ma, G., Chen, P., and Tolin, S. A. 2001. Genetic analysis of resistance to Soybean mosiac virus in OX670 and Harosoy soybean. Crop Sci. 41:1785-1791.

17. Gunsolus, J. L., and Curran, W. S. Herbicide mode of action and injury symptoms. University of Minnesota Extension Service. Published online.

18. Haile, F. J., Higley, I. G., and Specht, J. E. 1998. Soybean cultivars and insect defoliation: Yield loss and economic injury levels. Agron. J. 90:344-352.

19. Halbert, S. E., and Irwin, M. E. 1981. Effect of soybean canopy closure on landing rates of aphids with implications for restricting spread of soybean mosaic virus. Ann. Appl. Biol. 98:15-19.

20. Halbert, S. E., Irwin, M. E., and Goodman, R. M. 1981. Alate aphid (Homoptera: Aphididae) species and their relative importance as field vectors of soybean mosaic virus. Ann. Appl. Biol. 97:1-9.
21. Hayes, A. J., Ma, G., Buss, G. R., and Maroof, M. A. S. 2000. Molecular marker mapping of $R s v 4$, a gene conferring resistance to all known strains of soybean mosaic virus. Crop Sci. 40:1434-1437.

22. Hill, J. H., Alleman, R., Hogg, D. B., and Grau, C. R. 2001. First report of transmission of Soybean mosaic virus and Alfalfa mosaic virus by Aphis glycines in the New World. Plant Dis. 85:561.

23. Hill, J. H., Bailey, T. B., Benner, H. I., Tachibana, T., and Durand, D. P. 1987. Soybean mosaic virus: Effects of primary disease incidence on yield and seed quality. Plant Dis. 71:237239.

24. Hill, J. H., Benner, H. I., Permar, T. A., Bailey, T. B., Andrews, R. E., Jr., Durand, D. P., and Van Deusen, R. A. 1989. Differentiation of soybean mosaic virus isolates by onedimensional trypsin peptide maps immunoblotted with monoclonal antibodies. Phytopathology 79:1261-1265.

25. Hill, J. H., Lucas, B. S., Benner, H. I., Tachibana, H., Hammond, R. B., and Pedigo, L. P. 1980. Factors associated with the epidemiology of soybean mosaic virus in Iowa. Phytopathology 70:536-540.

26. Hobbs, H. A., Hartman, G. L., Wang, Y., Hill, C. B., Bernard, R. L., Pedersen, W. L., and Domier, L. L. 2003. Occurrence of seed coat mottling in soybean plants inoculated with Bean pod mottle virus and Soybean mosaic virus. Plant Dis. 87:1333-1336.

27. Holliday, M. J., and Keen, N. T. 1982. The role of phytoalexins in the resistance of soybean leaves to bacteria: Effect of glyphosate on glyceollin accumulation. Phytopathology 72:1470-1474.

28. Horvath, J., and Hunyadi, K. 1973. Studies on the effect of herbicides on virus multiplication. Acta Phytopathol. Acad. Sci. Hung. 8:347-350.

29. Irwin, M. E., and Goodman, R. M. 1981 Ecology and control of soybean mosaic virus. Pages 181-220 in: Plant Diseases and Vectors: Ecology and Epidemiology. K. Maramorosch and K. F. Harris, eds. Academic Press, New York.

30. Irwin, M. E., and Ruesink, W. G. 1986. Vector intensity: A product of propensity and activity. Pages 13-33 in: Plant Virus Epidemics: Monitoring, Modeling, and Predicting Outbreaks. G. D. McLean, ed. Academic Press, North Ryde, NSW.

31. Irwin, M. E., Ruesink, W. G., Isard, S. A., and Kampmeier, G. E. 2000. Mitigating epidemics caused by non-persistently transmitted aphidborne viruses: The role of the pliant environment. Virus Res. 71:185-211.

32. Keen, N. T., Holliday, M. J., and Yoshikawa, M. 1982. Effects of glyphosate on glyceollin production and the expression of resistance to Phytophthora megasperma f. sp. glycinea in soybean. Phytopathology 72:1467-1470.

33. Koning, G., TeKrony, D. M., and Ghabrial, S. A. 2003. Soybean seedcoat mottling: Association with Soybean mosaic virus and Phomopsis spp. seed infection. Plant Dis. 87:413-417.

34. Lee, M. E., Kurtzweil, N. C., Boerboom, C., Gaska, J., and Grau, C. R. 2002. Agronomic performance of soybeans (Glycine max) in the presence of Soybean mosaic virus and the herbicides glyphosate and imazamox. (Abstr.) Phytopathology 92:S45

35. Lee, M. E., Kurtzweil, N. C., Boerboom, C., Gaska, J., and Grau, C. R. 2002. Impact of soybean canopy on aphid immigration and Soybean mosaic virus incidence. (Abstr.) Phytopathology 92:S46.

36. Levine, B. C., Owen, M. D. K., and Tylka, G. L. 1998. Response of soybean cyst nematodes and soybeans (Glycine max) to herbicides. Weed Sci. 46:264-270.

37. Li, W. M., and Pu, Z. Q. 1991. Population dynamics of aphids and epidemics of soybean 
mosaic virus in summer sown soybean fields. Acta Phytophylactica Sin. 18:123-126.

38. Macedo, T. B., Bastos, C. S., Higley, L. G., Ostlie, K. R., and Madhavan, S. 2003. Photosynthetic responses of soybean to soybean aphid (Homoptera: Aphididae) injury. J. Econ. Entomol. 96:188-193.

39. MacKay, D. B., Ader, F., Gordon, A. G., and Hutin, C. 1976. ISTA: International rules for seed testing. Seed Sci. Technol. 4:3-49.

40. Nelson, K. A., Renner, K. A., and Hammerschmidt, R. 2002. Cultivar and herbicide selection affects soybean development and the incidence of Sclerotinia stem rot. Agron. J. 94:1270-1281.

41. Nutter, F. W., and Littrell, R. H. 1996. Relationships between defoliation, canopy reflectance and pod yield in the peanut-late leafspot pathosystem. Crop Prot. 15:135-142.

42. Pacumbaba, R. P. 1990. Seed transmission of soybean mosaic virus using mottled seeds from virus-infected soybean plants. Soybean Genet. Newsl. 17:144-146.

43. Pacumbaba, R. P. 1995. Seed transmission of soybean mosaic virus in mottled and nonmottled soybean seeds. Plant Dis. 79:193-195.

44. Padgette, S. R., Kolacz, K. H., Delannay, X., Re, D. B., LaVallee, B. J., Tinius, C. N., Rhodes, W. K., Otero, Y. I., Barry, G. F., and Eichholtz, D. A. 1995. Development, identification, and characterization of a glyphosate-tolerant soybean line. Crop Sci. 35:1451-1461.

45. Ragsdale, D. W., Voegtlin, D. J., and O'Neil, R. J. 2004. Soybean aphid biology in North America. Ann. Entomol. Soc. Am. 97:204-208.

46. Ruesink, W. G., and Irwin, M. E. 1986. Soybean mosaic virus epidemiology: A model and some implications. Pages 295-313 in: Plant Virus Epidemics: Monitoring, Modeling and Predicting Outbreaks. G. D. McLean, R. G. Garrett, and W. G. Ruesink, eds. Academic Press, North Ryde, NSW.

47. Russell, T. S. 1988. Some aspects of sampling and statistics in seed health testing and the establishment of threshold levels. Phytopathology 78:880-881.

48. Rutledge, C. E., O’Neil, R. J., Fox, T. B., and Landis, D. A. 2004. Soybean aphid predators and their use in integrated pest management. Ann. Entomol. Soc. Am. 97:240-248.

49. Sanogo, S., Yang, X. B., and Scherm, H. 2000. Effects of herbicides on Fusarium solani f. sp. glycines and development of sudden death syndrome in glyphosate-tolerant soybean. Phytopathology 90:57-66.

50. Shaner, D. L. 1991. Physiological effects of the imidazolinone herbicides. Pages 129-137 in: The Imidazolinone Herbicides. D. L. Shaner and S. L. O'Connor, eds. CRC Press, Boca Raton, FL.

51. Sinclair, J. B. 1999. Compendium of Soybean Diseases. 4th ed. G. L. Hartman, J. B. Sinclair, and J. C. Rupe, eds. American Phytopathological Society, St. Paul, MN.

52. Snedecor, G. W., and Cochran, W. G. 1989. Statistical Methods. 8th ed. Iowa State University Press, Ames.

53. Steinlage, T. A., Hill, J. H., and Nutter, F. W., Jr. 2002. Temporal and spatial spread of Soybean mosaic virus (SMV) in soybeans transformed with the coat protein gene of SMV. Phytopathology 92:478-486.

54. Venette, R. C., and Ragsdale, D. W. 2004. Assessing the invasion by soybean aphid (Ho- moptera: aphididae): Where will it end? Ann. Entomol. Soc. Am. 97:219-226.

55. Voegtlin, D. J., Halbert, S. E., and Qiao, G. 2004. A guide to separating Aphis glycines Matsumura and morphologically similar species that share its hosts. Ann. Entomol. Soc. Am. 97:227-232.

56. Voegtlin, D. J., O’Neil, R. J., and Graves, W. R. 2004. Tests of suitability of overwintering hosts of Aphis glycines: Identification of a new host association with Rhamnus alnifolia L'Heritier. Ann. Entomol. Soc. Am. 97:233-234.

57. Wang, R. Y., and Ghabrial, S. A. 2002. Effect of aphid behavior on efficiency of transmission of Soybean mosaic virus by the soybeancolonizing aphid, Aphis glycines. Plant Dis. 86:1260-1264.

58. Wang, S. Y., Boa, X. Z., Chen, R. L., and Zhai, B. P. 1996. Study on the effects of the population dynamics of soybean aphid on both growth and yield of soybean. Soybean Sci 15:243-247.

59. Ward, E. W. B. 1984. Suppression of metalaxyl activity by glyphosate: Evidence that host defense mechanisms contribute to metalaxyl inhibition of Phytophthora megasperma f. sp. glycinea in soybeans. Physiol. Plant Pathol. 25:381-386

60. Wu, Z., Schenk-Hamlin, D., Zhan, W. Ragsdale, D. W., and Heimpel, G. E. 2004 The soybean aphid in China: A historical review. Ann. Entomol. Soc. Am. 97:209-218.

61. Zhang, H. J. 1982. The relationship between population fluctuations of alates of the soyabean aphid and the epidemic level of soyabean virus disease in the field. Chinese Oil Crops Zhonggua Youliao 2:59-61. 